\title{
Effect of the microbial lactase (EC 3.2.1.23) activity in yoghurt on the intestinal absorption of lactose: an in vivo study in lactase-deficient humans*
}

\author{
BY PHILIPPE MARTEAU ${ }^{1}$, BERNARD FLOURIE ${ }^{1}$, PHILIPPE POCHART ${ }^{2}$, \\ CLAUDE CHASTANG ${ }^{3}$, JEHAN-FRANÇOIS DESJEUX ${ }^{1}$ \\ AND JEAN-CLAUDE RAMBAUD ${ }^{i}$ \\ ${ }^{1}$ INSERM U.290, Fonctions Intestinales, Métabolisme et Nutrition, Hôpital Saint-Lazare, 107 rue \\ du Faubourg Saint-Denis, 75010, Paris, ${ }^{2}$ Département de Microbiologie, Faculté de Pharmacie, \\ Université Paris XI, Chatenay Malabry, and ${ }^{3}$ Département de Biostatistiques et Informatique \\ Médicale, Hôpital Saint-Louis, Paris, France
}

(Received 2 August 1989 - Accepted 4 January 1990)

\begin{abstract}
Breath hydrogen excretion was measured in eight lactase $(E C$ 3.2.1.108)-deficient volunteers ingesting $18 \mathrm{~g}$ lactose in the form of milk, yoghurt and heated yoghurt. Total excess hydrogen excretion (area under curve) was significantly lower after yoghurt and heated yoghurt, than after milk: 103 (SE 29), 191 (SE 32), and 439 (SE 69) respectively $(P<0.001)$. The oro-caecal transit time of fermentable components from yoghurt and heated yoghurt (mainly lactose) was longer than that from milk: 165 (SE 17), 206 (SE 19), v. 103 (SE 19) $\min (P<0.01)$. An intestinal perfusion technique was used in the same subjects after ingestion on two consecutive days of $18 \mathrm{~g}$ lactose in yoghurt and heated yoghurt. Significantly less lactose was recovered from the terminal ileum after yoghurt than after heated yoghurt meals: 1740 (SE 260) $v$. 2825 (SE 461) $\mathrm{mg}(P<0.05)$, and approximately one-fifth of the lactase activity contained in yoghurt reached the terminal ileum. These findings indicate that more than $90 \%$ of the lactose in yoghurt is digested in the small intestine of lactase-deficient subjects and suggest that both the lactase activity contained in the viable starter culture and a slow oro-caecal transit time are responsible for this excellent absorption.
\end{abstract}

Lactose digestion: Lactase deficiency: Dairy products

It is now well established from breath hydrogen studies that lactase ( $E C$ 3.2.1.108)deficient subjects absorb lactose more efficiently from fresh yoghurt (Y) than from heated yoghurt (HY) or milk (Kolars et al. 1984; Savaiano et al. 1984; Dewit et al. 1988). This is believed to be due to the presence of lactase of microbial origin in yoghurt (Kolars et al. 1984; Pochart et al. 1989). However, neither the precise gain in lactose absorption from $Y$ compared with $\mathrm{HY}$, nor the fate of $\mathrm{Y}$ microbial lactase beyond the duodenum are known. The aims of the present study, performed in lactase-deficient healthy humans, were therefore to quantify directly the intestinal absorption of lactose after ingestion of $\mathrm{Y}$ and $\mathrm{HY}$, and to ascertain the fate and role of Y lactase in the small intestine.

\section{MATERIALS AND METHODS}

Subjects

Eight healthy volunteers (four men and four women, seven white and one black) who had not recently taken antibiotics or laxatives were studied. Their ages ranged from 19 to 27 years (mean 22 years), and all gave written informed consent to the protocol which was

* These findings were presented as an abstract at the meeting of the American Gastroenterological Association, New Orleans, Louisiana, 16 May 1988. 
approved by the Local Ethics Committee. The subjects were identified as lactose malabsorbers because their breath $\mathrm{H}_{2}$ concentrations exceeded 20 parts per million (ppm) after ingestion of $50 \mathrm{~g}$ lactose in $250 \mathrm{ml}$ water (Newcomer et al. 1975).

\section{Test meals}

In all experiments we used the same commercial unflavoured Y (Yoplait, Sodima) and whole milk. The HY was obtained by heating commercial yoghurts for $1 \mathrm{~h}$ in a stirred water bath at $70^{\circ}$, allowing the temperature of the yoghurt to rise to $65^{\circ}$ for the last $20 \mathrm{~min}$. $\mathrm{HY}$ was then immediately cooled to $4^{\circ}$ and was consumed within $24 \mathrm{~h}$ of heating. The lactose, galactose, glucose and lactase contents of milk, $\mathrm{Y}$ and $\mathrm{HY}$ are indicated in Table 1. In HY, bacterial lactase (EC 3.2.1.23) was very low, and kinetic studies showed us that under in vitro optimal conditions of $\mathrm{pH}$ and temperature it could not hydrolyse more than $10 \%$ of the lactose present in the meal.

\section{Methods}

End alveolar breath samples were obtained on three consecutive days from all eight nonsmoking subjects in the fasting state and then half-hourly for $9 \mathrm{~h}$ after ingestion in a random order of the following test meals (one on each of the three days): $400 \mathrm{ml}$ whole milk, $450 \mathrm{~g}$ commercial unflavoured $\mathrm{Y}$, and $450 \mathrm{~g}$ HY. Each test meal contained $18 \mathrm{~g}$ lactose and was ingested at $4^{\circ}$.

On the 4th day, each subject was intubated with a triple-lumen tube, tracted by a mercury bag (Phillips \& Giller, 1973). One lumen was used to inflate the bag in order to hasten tube progression. When the bag had reached the caecum, as confirmed fluoroscopically, subjects were asked to stay in a semi-recumbent position. The second lumen was used to sample ileal contents $15 \mathrm{~cm}$ above the ileo-caeal junction, and the third, $25 \mathrm{~cm}$ proximal to the aspiration port, was used for perfusion. On the morning of the 5 th and 6 th days, a $2 \mathrm{ml} / \mathrm{min}$ infusion of polyethyleneglycol 4000 (PEG: $10 \mathrm{~g} \mathrm{PEG} \mathrm{4000/1} \mathrm{saline} \mathrm{(154} \mathrm{mM-sodium}$ chloride) at $37^{\circ}$ ) was started. After $1 \mathrm{~h}$ of equilibration, fasting subjects ingested in a random order either the $\mathrm{Y}$ or $\mathrm{HY}$ meal in 4-10 min. Before ingestion, $30 \mu \mathrm{Ci}{ }^{14} \mathrm{C}$-labelled PEG and $10^{8}$ bacterial spores of Bacillus stearothermophilus germinating only at $65^{\circ}$ (Merck, Darmstadt, FRG) were added to the meals as meal and bacterial markers respectively (Besnier et al. 1983; Pochart et al. 1989) Ileal contents were constantly collected on ice by manual aspiration in order to aspirate as much fluid as possible during the $9 \mathrm{~h}$ after the beginning of the meals. Samples were separated into 30 -min portions. The $\mathrm{pH}$ of ileal fluid was measured immediately after collection and samples were frozen at $-20^{\circ}$ to prevent bacterial degradation of carbohydrates. Maintenance of the intestinal tube position was checked fluoroscopically at the end of all studies.

\section{Analysis}

$\mathrm{H}_{2}$ concentrations in expiratory gas samples were measured using an electrochemical cell (Exhaled Hydrogen Monitor, GMI Medical Ltd, Renfrew, Scotland). In ileal fluid, pH was measured with a pH meter (Radiometer, Copenhagen, Denmark), PEG by turbidimetry (Hydén, 1955), and ${ }^{14} \mathrm{C}$-labelled PEG by a scintillator counter (Intertechnique, Paris). The spore concentration of Bacillus stearothermophilus in each ileal sample was determined in duplicate as follows: six successive 1:10 dilutions of each sample in sterile saline were performed. Each diluted portion $(1 \mathrm{ml})$ was combined with $15 \mathrm{ml}$ sterile standard agar gelose (Plate Count Agar) at $65^{\circ}$, and incubated aerobically for $24 \mathrm{~h}$ at $65^{\circ}$, and bacterial colonies were counted. In milk, yoghurts and ileal samples, the lactose, galactose and glucose contents were assessed enzymically (Boehringer Biochemicals, Mannheim, FRG). Lactase activity was measured in $\mathrm{Y}, \mathrm{HY}$ and ileal samples as follows: after adequate 
Table 1. Carbohydrate and lactase (EC 3.2.1.23) content of the three test meals

(Mean values with their standard errors for ten determinations on each product)

\begin{tabular}{|c|c|c|c|c|c|c|}
\hline & \multicolumn{2}{|c|}{ Yoghurt } & \multicolumn{2}{|c|}{ Heated yoghurt } & \multicolumn{2}{|c|}{ Whole milk } \\
\hline & Mean & $\mathrm{SE}$ & Mean & $\mathrm{SE}$ & Mean & $\mathrm{SE}$ \\
\hline Lactose $(\mathrm{g} / \mathrm{l})$ & $39 \cdot 9$ & 0.4 & $39 \cdot 8$ & $0 \cdot 2$ & $45 \cdot 0$ & 0.5 \\
\hline Galactose $(\mathrm{g} / \mathrm{l})$ & $10 \cdot 1$ & $0 \cdot 1$ & $10 \cdot 1$ & $0 \cdot 1$ & & \\
\hline Glucose $(\mathrm{g} / \mathrm{l})$ & 0.02 & $0 \cdot 1$ & $0 \cdot 1$ & $0 \cdot 1$ & & \\
\hline Lactase (IU/g) & $1 \cdot 7$ & 0.1 & $0 \cdot 3$ & 0.1 & & \\
\hline
\end{tabular}

dilution in $0.1 \mathrm{M}$-sodium phosphate ( $\mathrm{pH} \mathrm{7)}$ and sonication for $1 \mathrm{~min}$ in an ice bath, a $1 \mathrm{ml}$ portion of each sample was incubated with $4 \mathrm{ml} 0.005$ M-ortho-nitrophenyl- $\beta$-Dgalactopyranoside (ONPG). The reaction, which proceeded at $37^{\circ}$, was stopped after $10 \mathrm{~min}$ by adding $5 \mathrm{ml}$ of cold $0.5 \mathrm{M}$-sodium carbonate solution. Absorbance was read at $420 \mathrm{~nm}$ in a spectrophotometer and compared with the absorbance read on a standard curve prepared with ortho-nitrophenol (ONP). The lactase (EC 3.2.1.23) activity unit (IU) was defined as the amount needed to hydrolyse $1 \mu \mathrm{mol}$ ONPG $/ \mathrm{min}$ at $37^{\circ}$. To study the influence of freezing on lactase activity and lactose content in ileal samples, both were measured before and after freezing in the first two experiments, and were not found to be modified. High levels of lactose, galactose or glucose might theoretically inhibit weakly the lactase activity measured with ONPG (Itoh et al. 1980; Greenberg \& Mahoney 1982; Mahoney, 1985). To ensure that this phenomenon did not occur, the lactase activity was measured in a series of ileal samples before and after dialyzing overnight in phosphate buffered saline; dialyzing eliminated the sugars from the samples but did not modify the lactase activity.

\section{Calculations}

Total excess $\mathrm{H}_{2}$ excreted in breath after test meals was determined by integrating the area under the $\mathrm{H}_{2}$ concentration curve located between a sharp increase $(>5 \mathrm{ppm})$ and the return of $\mathrm{H}_{2}$ to baseline values (Flourié et al. 1986). Oro-caecal transit time was defined as the time elapsing between the beginning of meal ingestion and the sharp increase in breath $\mathrm{H}_{2}$.

The volume flowing through the terminal ileum for each 30 -min period of sampling was calculated by unlabelled PEG dilution, and standard formulas were corrected for the volume of marker fluid infused, assuming that it was not absorbed in the $25 \mathrm{~cm}$ segment between the infusion and aspiration sites (Phillips \& Giller, 1973). Ileal flow of ${ }^{14} \mathrm{C}$-labelled PEG and spores ingested in the meal were calculated from the amounts of ${ }^{14} \mathrm{C}$-labelled PEG and spores aspirated, after correction for recovery of the ileal marker. The amounts of lactose, galactose, glucose and lactase in each ileal sample were determined from the calculated ileal volume (without subtraction of the perfused volume) and from the carbohydrate and lactase concentrations in the sample. The total ileal content for $9 \mathrm{~h}$ was obtained by the summation of results for individual periods.

\section{Statistical analysis}

Results are expressed as means with their standard errors. Values were compared by analysis of variance using the SAS software. 


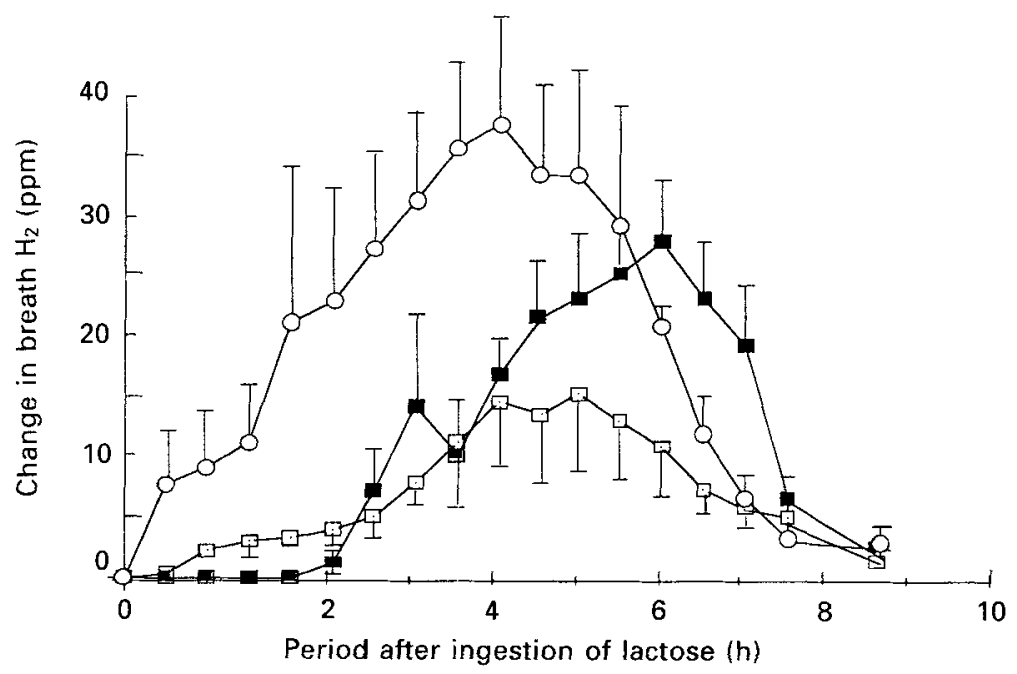

Fig. 1. Changes in breath hydrogen after ingestion of $18 \mathrm{~g}$ lactose in milk $(O)$, heated yoghurt ( $\square$ ) or yoghurt ( $\square$ ) by lactase $(E C 3.2 .1 .108)$-deficient subjects. Values are means with their standard errors represented by vertical bars for eight subjects. For details of procedures, see p. 72.

\section{RESULTS}

Breath $\mathrm{H}_{2}$ excretion after meals

Fig. 1 shows the changes in breath $\mathrm{H}_{2}$ after ingestion of milk and yoghurts. The area under the curve was significantly higher for milk than for HY and $Y(P<0.001)$ (Table 2). The difference between the area under the curve for $\mathrm{Y}$ and $\mathrm{HY}$ did not reach statistical significance when the variance of the three treatments was considered $(P=0.08)$. A significantly shorter oro-caecal transit time was measured after milk than after HY and $\mathrm{Y}$ $(P<0.05)$ (Table 2$)$.

Water flow and $\mathrm{pH}$ of the distal ileum and recovery of meal markers

The mean flow of water through the terminal ileum for the $9 \mathrm{~h}$ after $\mathrm{Y}$ ingestion was not significantly different from that calculated after HY, i.e. 645 (SE 161) v. 569 (SE 156) $\mathrm{ml}$. The $\mathrm{pH}$ of the ileal fluid was not affected by the Y or HY meals in comparison with basal fasting values (range 6.6-7.8).

The time-course of passage through the ileum of ${ }^{14} \mathrm{C}$-labelled PEG and spores followed roughly the same pattern, and did not differ for Y and HY meals (Fig. 2). The ${ }^{14} \mathrm{C}$-labelled PEG and the spores of test meals always appeared in ileal samples within $1 \mathrm{~h}$ of the beginning of meal ingestion and sometimes as early as $30 \mathrm{~min}$. The percentages of ${ }^{14} \mathrm{C}$ labelled PEG and spores ingested in $\mathrm{Y}$ which were recovered from the terminal ileum during the $9 \mathrm{~h}$ aspiration period were 96 (SE 3) and 99 (SE 10) respectively (ranges 90-105 and 85-120). They were not significantly different from those calculated after HY, i.e. 96 (SE 3) and 95 (SE 12) respectively (ranges 87-104 and 85-120).

\section{Carbohydrate recovery from the terminal ileum}

Lactose, galactose and glucose recovery in the terminal ileum followed roughly the same pattern as that of ${ }^{14} \mathrm{C}$-labelled $\mathrm{PEG}$ and spores. The mean amounts of lactose not absorbed by the small intestine during the $9 \mathrm{~h}$ post-ingestion period were significantly lower after $\mathrm{Y}$ than after HY $(P<0.05)$ (Table 3, Fig. 3). The mean amounts of galactose and glucose 
Table 2. Breath hydrogen excretion after ingestion of $18 \mathrm{~g}$ lactose in yoghurt, heated yoghurt or milk in eight lactase (EC 3.2.1.108)-deficient subjects

(Mean values with their standard errors)

\begin{tabular}{|c|c|c|c|c|}
\hline & \multicolumn{2}{|c|}{ Area under curve } & \multicolumn{2}{|c|}{$\begin{array}{l}\text { Oro-caecal transit time } \\
\qquad(\mathrm{min})\end{array}$} \\
\hline & Mean & SE & Mean & $\mathbf{S E}$ \\
\hline Yoghurt (Y) & 103 & 29 & 165 & 17 \\
\hline Heated yoghurt (HY) & 191 & 32 & 206 & 19 \\
\hline $\operatorname{Milk}(\mathrm{M})$ & 439 & 69 & 103 & 19 \\
\hline $\operatorname{SED}(14 \mathrm{df})$ & \multicolumn{2}{|c|}{110} & \multicolumn{2}{|c|}{55} \\
\hline \multicolumn{5}{|l|}{$\begin{array}{l}\text { Significance of } \\
\text { comparisons: }\end{array}$} \\
\hline $\mathrm{Y} v . \mathrm{M}$ & \multicolumn{2}{|c|}{$P<0.001$} & \multicolumn{2}{|c|}{$P<0.01$} \\
\hline $\mathrm{Y} v . \mathrm{HY}$ & \multicolumn{2}{|c|}{$P=0.08$} & \multicolumn{2}{|c|}{ NS } \\
\hline HY v. M & \multicolumn{2}{|c|}{$P<0.001$} & \multicolumn{2}{|c|}{$P<0.001$} \\
\hline
\end{tabular}

SED, standard error of the difference; NS, not significant.

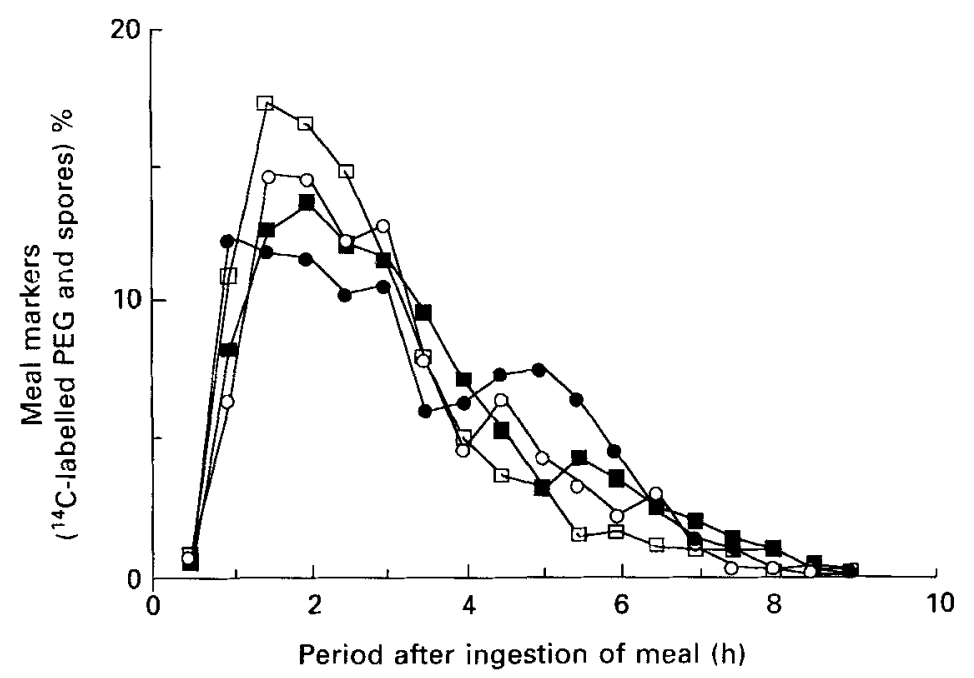

Fig. 2. Time-courses of the passage of the meal markers ${ }^{14} \mathrm{C}$-labelled polyethylene glycol $(\mathrm{O}, \mathrm{O})$ and bacterial spores $(\square, \square)$ through the ileum after ingestion of yoghurt $(O, \square)$ or heated yoghurt $(\boldsymbol{O}, \square)$ by eight lactasedeficient subjects. For details of procedures, see p. 72 .

present in the ileal samples did not differ between $Y$ and HY (Table 3). When the values were expressed as hexose units ( $\mathrm{mmol}$ of lactose $\times 2+\mathrm{mmol}$ of galactose and glucose), the mean amounts of hexoses malabsorbed by the small intestine were significantly lower after $\mathrm{Y}$ than after HY $(P<0.05)$ (Table 3$)$.

\section{Lactase recovery from the terminal ileum}

After ingestion of $Y$, a significant and important increase in lactase flow rate was observed which followed the same time course as the meal markers (Fig. 4). In contrast, compared with late values, the lactase activity of ileal fluid was not affected by HY (Fig. 4). The mean amounts of lactase recovered during the $9 \mathrm{~h}$ were significantly higher $(P<0.01)$ after Y (192 (SE 37), range 70-333 IU) than after HY (47 (SE 7), range 21-74 IU). 
Table 3. Amounts of unabsorbed sugars recovered in $9 \mathrm{~h}$ from the terminal ileum in eight lactase (EC 3.2.1.108)-deficient subjects ingesting $18 \mathrm{~g}$ lactose in yoghurt and heated yoghurt

(Mean values with their standard errors, ranges in parentheses)

\begin{tabular}{|c|c|c|c|c|c|c|c|c|}
\hline & \multicolumn{2}{|c|}{$\begin{array}{l}\text { Lactose } \\
\text { (mg) }\end{array}$} & \multicolumn{2}{|c|}{$\begin{array}{l}\text { Galactose } \\
\text { (mg) }\end{array}$} & \multicolumn{2}{|c|}{$\begin{array}{l}\text { Glucose } \\
\text { (mg) }\end{array}$} & \multicolumn{2}{|c|}{$\begin{array}{c}\text { Hexoses } \\
\text { (hexose units) }\end{array}$} \\
\hline & Mean & SE & Mean & $\mathrm{SE}$ & Mean & SE & Mean & SE \\
\hline Yoghurt (Y) & \multicolumn{2}{|c|}{$(2942534)$} & \multicolumn{2}{|c|}{$\begin{array}{lr}725 & 178 \\
(127 & -1380)\end{array}$} & \multicolumn{2}{|c|}{$\begin{array}{c}333 \quad 112 \\
(85-1048)\end{array}$} & \multicolumn{2}{|c|}{$\begin{array}{cc}14.9 & 2.4 \\
(2.8-23.4)\end{array}$} \\
\hline Heated yoghurt (HY) & \multicolumn{2}{|c|}{$(494-4225)$} & \multicolumn{2}{|c|}{$(20-1086)$} & \multicolumn{2}{|c|}{$(12-463)$} & \multicolumn{2}{|c|}{$(3 \cdot 0-28 \cdot 7)$} \\
\hline $\operatorname{SED}(14 \mathrm{df})$ & \multicolumn{2}{|c|}{635} & \multicolumn{2}{|c|}{234} & \multicolumn{2}{|c|}{236} & \multicolumn{2}{|c|}{3.45} \\
\hline $\begin{array}{l}\text { Significance of } \\
\text { comparisons } \mathrm{Y} v \mathrm{HY}\end{array}$ & \multicolumn{2}{|c|}{$P=0.011$} & \multicolumn{2}{|c|}{$P=0.09$} & \multicolumn{2}{|c|}{$P=0.3$} & \multicolumn{2}{|c|}{$P=0.033$} \\
\hline
\end{tabular}

SED, standard error of the difference.

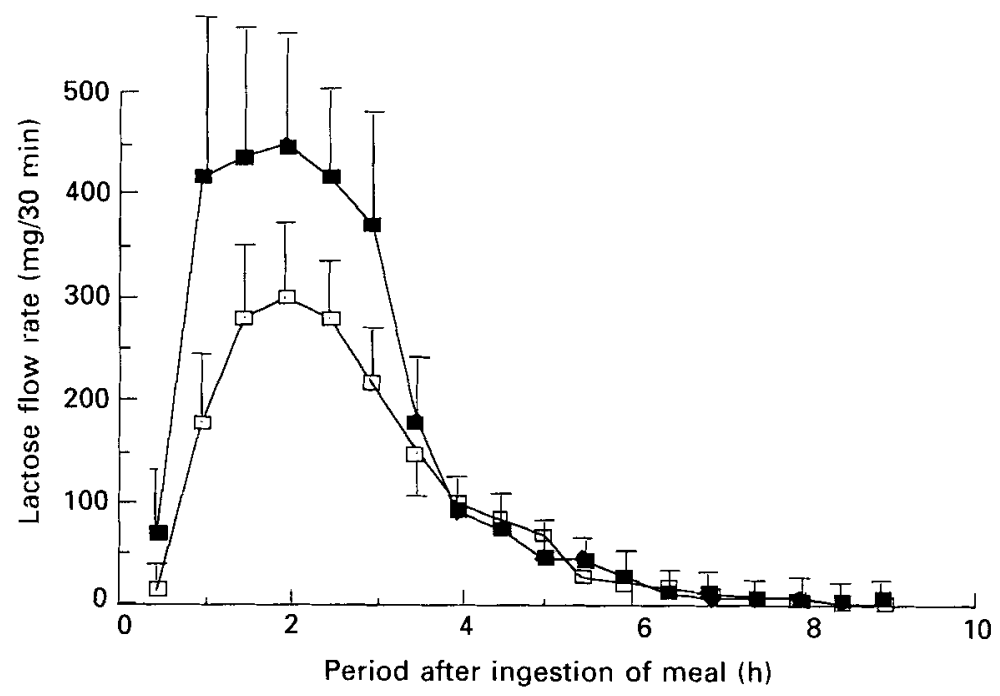

Fig. 3. Lactose flow rate through the ileum after ingestion of yoghurt ( $\square$ ) or heated yoghurt ( $\square$ ). Values are means with their standard errors represented by vertical bars for eight lactase-deficient subjects. For details of procedures, see p. 72 .

\section{DISCUSSION}

The present work aimed to quantify directly the lactose absorption from $\mathrm{Y}$ and $\mathrm{HY}$ in lactase-deficient subjects, and to define the fate and role of $\mathrm{Y}$ microbial lactase in the human small intestine.

Previous breath $\mathrm{H}_{2}$ tests showed that lactose is significantly better absorbed from $Y$ than from HY, and from HY than from milk (Kolars et al. 1984; Savaiano et al. 1984; Dewit et al. 1988). The present work confirms this finding. Moreover, direct measurement of the residual sugars recovered from the terminal ileum after ingestion of $450 \mathrm{~g}$ yoghurt (i.e. 155 hexose units) showed that only $9.6 \%$ of the sugar load was malabsorbed. We did not 


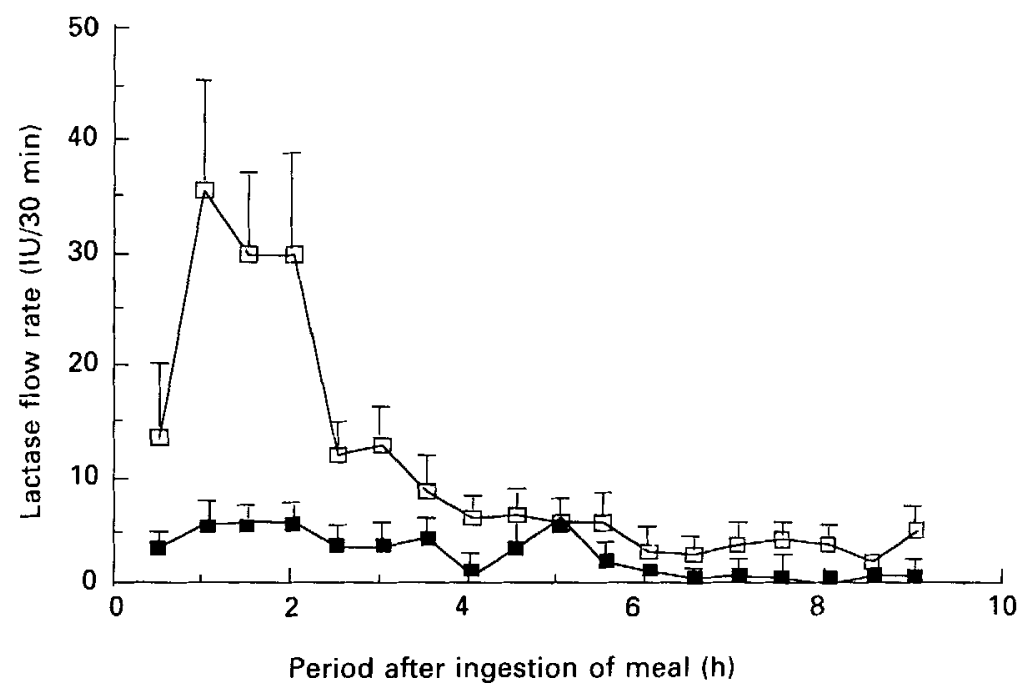

Fig. 4. Lactase flow rate through the ileum after ingestion of yoghurt $(\square)$ or heated yoghurt ( $\square$ ) by lactase (EC 3.2.1.108)-deficient subjects. Values are means with their standard errors represented by vertical bars for eight subjects. For details of procedures, see p. 72.

measure directly carbohydrate malabsorption from milk; however, using the amount of $\mathrm{H}_{2}$ excreted and the known quantity of hexoses malabsorbed after $\mathrm{Y}$ and $\mathrm{HY}$ meals, we calculated from the breath $\mathrm{H}_{2}$ excretion that about 39 (SE 6) \% of the hexoses in the milk were not absorbed by our subjects. This value agrees with the findings in the literature for both $\mathrm{H}_{2}$ breath tests (Kolars et al. 1984) and direct measurements (Bond \& Levitt, 1976; Debongnie et al. 1979). Hydrolysis of lactose from $Y$ reached $90 \cdot 3 \%$, but significant amounts of galactose and glucose were recovered from the ileal fluid, possibly due to the fact that some of the lactose hydrolysis occurred in vitro. However, glucose recovery was significantly lower than that of galactose, which seems to imply incomplete absorption of the hexoses derived from in vivo lactose hydrolysis near the sampling port (Gray \& Santiago, 1966; Rambaud et al. 1968).

It has been shown that the lactase activity in $\mathrm{Y}$ is not completely denatured during its passage through the stomach, and can be detected in the duodenum (Kolars et al. 1984; Pochart et al. 1989). This resistance to gastric acidity depends on both the buffering capacity of $\mathrm{Y}$ and the integrity of the bacterial cell membrane (Martini et al. 1987). However, in the duodenum of lactase-deficient subjects, Y microbial lactase is not active because of the low pH (Pochart et al. 1989), and its fate downstream, where a suitable $\mathrm{pH}$ occurs, had not previously been known. Our study demonstrates that about one-fifth of the $Y$ bacterial lactase reaches the terminal ileum with a time-course identical to that of lactose. However, it should be pointed out that the better absorption of $Y$ lactose than milk lactose observed here may not only be due to bacterial lactase activity since the percentage of hexoses malabsorbed was only $12.5 \%$ from HY $v 39 \%$ from milk. In HY, bacterial lactase was very low, and kinetic studies showed us that under in vitro optimal conditions of $\mathrm{pH}$ and temperature it could not hydrolyze more than $10 \%$ of the lactose present in the meal. Furthermore, we have previously shown that after ingestion of HY, the lactase activity was negligible in the duodenal contents of lactase-deficient subjects (Pochart et al. 1989) so that this hydrolysis rate is unlikely to occur in vivo. The oro-caecal transit time of Y and HY meals, as determined from the breath $\mathrm{H}_{2}$ tests, was significantly longer than that of whole 
milk. Assuming that $10 \%$ of the intestinal lactase activity persists in adult lactase-deficient subjects (Asp et al. 1971), this delay in gastrointestinal transit might partly explain the better digestion of $\mathrm{Y}$ and HY lactose $v$. milk lactose. In lactase-deficient subjects, such a mechanism has indeed already been proposed to explain the better absorption of equivalent amounts of lactose from whole milk compared with skimmed milk, or of lactose taken with a meal or with chocolate or fibre (Welsh \& Hall, 1977; Solomons et al. 1979, 1985; Nguyen et al. 1982; Martini \& Savaiano, 1988; Lee \& Hardy 1989).

In conclusion, more than $90 \%$ of the carbohydrates in $\mathrm{Y}$ are digested in the small intestine of lactase-deficient subjects. Such absorption is in part due to the bacterial lactase activity since (a) lactose absorption is significantly lower after HY ingestion, and (b) onefifth of the lactase activity from ingested $Y$ reaches the terminal ileum at the same time as lactose. However, an improved hydrolysis of lactose by the residual intestinal lactase activity may also be involved, as lactose absorption from HY (in which the bacterial lactase activity is destroyed) remains markedly higher than lactose absorption from milk, and could be due to the slower oro-caecal transit time of $\mathrm{Y}$ and HY compared with milk.

The authors with to thank C. Franchisseur and M. Maurel for their technical assistance. This work was supported in part by the Yoplait International Institute as one of its Competitive Research Projects.

\section{REFERENCES}

Asp, N. G., Berg, N. O., Dahlqvist, A., Jussila, J.\& Salmi, H. (1971). The activity of three different small intestinal $\beta$-galactosidases in adults with and without lactase deficiency. Scandinavian Journal of Gastroenterology 6 , $755-762$

Besnier, M. O., Bourlioux, P., Fourniat, J., Ducluzeau, R. \& Aumaitre, A. (1983). Influence de l'ingestion de yogourt sur l'activité lactasique intestinale chez des souris axéniques ou holoxéniques, Annales de Microbiologie 134, 219-230.

Bond, J. H. \& Levitt, M. D. (1976). Quantitative measurement of lactose absorption. Gastroenterology 70, $1058-1062$.

Debongnie, J. C., Newcomer, A. D., McGill, D. B. \& Phillips, S. F. (1979). Absorption of nutrients in lactase deficiency. Digestive Diseases and Sciences 24, 225-231.

Dewit, O., Pochart, P. \& Desjeux, J. F. (1988). Breath hydrogen concentration and plasma glucose, insulin and free fatty acid levels after lactose, milk, fresh and heated yoghurt ingestion by healthy young adults with or without lactose malabsorption. Nutrition 4, 1-5.

Flourié, B., Florent, C., Jouany, J. P., Thivend, P., Etanchaud, F. \& Rambaud, J. C. (1986). Colonic metabolism of wheat starch in healthy humans. Effects on fecal outputs and clinical symptoms. Gastroenterology 90 , $111-119$.

Gray, G. M. \& Santiago, N. A. (1966). Disaccharide absorption in normal and diseased human intestine. Gastroenterology 51, 489-498.

Greenberg, N. A. \& Mahoney, R. R. (1982). Production and characterization of $\beta$-galactosidase from Streptococcus thermophilus. Journal of Food Science 47, 1824-1829.

Hydén, S. (1955). A turbidimetric method for the determination of high polyethylene glycols in biological materials. Annals of the Royal Agriculture College of Sweden 22, 139-145.

Itoh, T., Ohhashi, M., Toba, T. \& Adachi, S. (1980). Purification and properties of $\beta$-galactosidase from Lactobacillus bulgaricus. Milchwissenschaft 35, 593-597.

Kolars, J. C., Levitt, M. D., Aouji, M. \& Savaiano, D. A. (1984). Yoghurt: an autodigesting source of lactose. New England Journal of Medicine 310, 1-3.

Lee, C. M. \& Hardy, C. M. (1989). Cocoa feeding and human lactose intolerance. American Journal of Clinical Nutrition 49, 840-844.

Mahoney, R. R. (1985). Modification of lactose and lactose-containing dairy products with $\beta$-galactosidase. In Developments in Dairy Chemistry - 3, pp 69-109 [P, F. Fox, editor]. London: Elsevier Applied Science Publishers.

Martini, M. C., Bollweg, G. L., Levitt, M. D. \& Savaiano, D. A. (1987). Lactose digestion by yoghurt bgalactosidase: influence of $\mathrm{pH}$ and microbial cell integrity. American Journal of Clinical Nutrition 45, 432-436.

Martini, M. C. \& Savaiano, D. A. (1988). Reduced intolerance symptoms from lactose consumed during a meal. American Journal of Clinical Nutrition 47, 57-60.

Newcomer, A. D., McGill, D. B., Thomas, P. J. \& Hofmann, A. F. (1975). Prospective comparison of indirect methods for detecting lactase deficiency. New England Journal of Medicine 293, 1232-1236. 
Nguyen, K. N., Welsh, J. D., Manion, C. V. \& Ficken, V. J. (1982). Effect of fiber on breath hydrogen response and symptoms after oral lactose in lactose malabsorbers. American Journal of Clinical Nutrition 35, 1347-1351.

Phillips, S. F. \& Giller, J. (1973). The contribution of the colon to electrolyte and water conservation in man. Journal of Laboratory and Clinical Medicine 81, 733-746.

Pochart, P., Dewit, O., Desjeux, J. F. \& Bourlioux, P. (1989). Viable starter culture, $\beta$-galactosidase activity and lactose in the duodenum; after yoghurt ingestion in lactase-deficient humans. American Journal of Clinical Nutrition 49, 828-831.

Rambaud, J. C., Sraer, J. D., Vidon, N., Fabia, F.\& Bernier, J. J. (1968). Absorption intestinale du glucose et du lactose chez l'homme. Etude de 24 sujets normaux par la technique de perfusion intestinale. Biologie Gastroentérologie 1, 61-74.

Savaiano, D. A., Anouar, A. A. E., Smith, D. E. \& Levitt, M. D. (1984). Lactose malabsorption from yoghurt, pasteurized yoghurt, sweet acidophilus milk, and cultured milk in lactase-deficent individuals. American Journal of Clinical Nutrition 40, 1219-1223.

Solomons, N. W., Garcia-Ibanez, R. \& Viteri, F. E. (1979). Reduced rate of breath hydrogen excretion with lactose tolerance tests in young children using whole milk. American Journal of Clinical Nutrition 32, 783-786.

Solomons, N. W., Guerrero, A. M. \& Torun, B. (1985). Dietary manipulation of postprandial colonic lactose fermentation. I. Effect of solid food in a meal. American Journal of Clinical Nutrition 41, 199-208.

Welsh, J. D. \& Hall, W. H. (1977). Gastric emptying of lactose and milk in subjects with lactose malabsorption. Digestive Diseases and Sciences 22, 1060-1063. 